\title{
Seabirds and the Circulation of Lyme Borreliosis Bacteria in the North Pacific
}

\author{
Elisa Lobato,, Jessica Pearce-Duvet,, Vincent Staszewski, ${ }^{1}$ Elena Gómez-Díaz,, ${ }^{3,4}$ Jacob González-Solís, \\ Alexander Kitaysky, ${ }^{6}$ Karen D. McCoy, ${ }^{4}$ and Thierry Boulinier ${ }^{1}$
}

\begin{abstract}
Seabirds act as natural reservoirs to Lyme borreliosis spirochetes and may play a significant role in the global circulation of these pathogens. While Borrelia burgdorferi sensu lato (Bbsl) has been shown to occur in ticks collected from certain locations in the North Pacific, little is known about interspecific differences in exposure within the seabird communities of this region. We examined the prevalence of anti-Bbsl antibodies in 805 individuals of nine seabird species breeding across the North Pacific. Seroprevalence varied strongly among species and locations. Murres (Uria spp.) showed the highest antibody prevalence and may play a major role in facilitating Bbsl circulation at a worldwide scale. Other species showed little or no signs of exposure, despite being present in multispecific colonies with seropositive birds. Complex dynamics may be operating in this wide scale, natural host-parasite system, possibly mediated by the host immune system and host specialization of the tick vector.
\end{abstract}

Key Words: Antibodies-Borrelia-Epidemiology_Emerging infectious diseases-Ixodes-North Pacific Ocean-Seabirds-Serology-Zoonosis.

\section{Introduction}

L YME BORRELIOSIS (LB) is currently the most prevalent vector-borne zoonosis in North America and Europe and is caused by certain species of the Borrelia burgdorferi complex, which are transmitted by Ixodes ticks (Kurtenbach et al. 2006). Although birds, small mammals, and lizards are all natural reservoirs of $B$. burgdorferi sensu lato (Bbsl), birds may play a key role in the dissemination and spatial distribution of Borrelia, notably as a result of their migratory behavior (Olsen et al. 1993, 1995, Kurtenbach et al. 1998, Comstedt et al. 2006, Duneau et al. 2008, Brinkerhoff et al. 2009, Dubska et al. 2009). Seabirds may be particularly important in the global circulation of LB spirochetes (Olsen et al. 1995); these birds are widely distributed and breed in large groups that often include a diverse range of interacting species (Schreiber and Burger 2001). The tick Ixodes uriae parasitises several of these seabird species in polar areas (Choe and Kim 1987, Dietrich et al. 2011) and has been shown to be infected with Bbsl in colonies of both Hemispheres (Olsen et al. 1993, 1995, Gylfe et al. 1999, Smith et al. 2006, Duneau et al. 2008, Comstedt et al. 2009). However, host-dependent population structure has been found for I. uriae ticks (McCoy et al. 2001, 2005a,b) and different local tick-seabird species combinations show variation in Bbsl infection prevalence and intensity (GómezDíaz et al. 2010), which may influence the circulation of the pathogens within the marine system (Duneau et al. 2008, McCoy 2008). Studying the exposure of different seabird host species to $\mathrm{Bbsl}$ is thus of major importance for identifying the host species involved in pathogen circulation.

Antibody $(\mathrm{Ab})$ prevalence reflects both past and present exposure of hosts to parasites. A few studies have investigated the prevalence of anti-Borrelia antibodies in seabirds (Gauthier-Clerc et al. 1999, Gylfe et al. 1999, Gasparini et al. 2001, Staszewski et al. 2008), but the number of species and locations considered in these studies is often limited. In the

\footnotetext{
${ }^{1}$ Centre d'Ecologie Fonctionnelle et Evolutive, CNRS UMR 5175, Montpellier, France.

${ }^{2}$ Institute of Infection and Immunology Research, School of Biological Sciences, Ashworth Laboratories, University of Edinburgh, Edinburgh, Scotland, United Kingdom.

${ }^{3}$ Institute of Evolutionary Biology (CSIC-UPF), Barcelona, Spain.

${ }^{4}$ MIVEGEC (Maladies Infectieuses et Vecteurs: Ecologie, Génétique, Evolution et Contrôle) UMR 5290 CNRS/IRD, UR 244 IRD, Montpellier, France.

${ }^{5}$ Departament de Biologia Animal, Universitat de Barcelona, Barcelona, Spain.

${ }^{6}$ Institute of Arctic Biology, University of Alaska Fairbanks, Fairbanks, Alaska.
} 
North Atlantic, significant spatial and interspecific variability in exposure to spirochetes has been reported (Staszewski et al. 2008), and the anti-Borrelia Ab levels of individual birds was shown to be highly stable between years in one wide-spread species, the black-legged kittiwake Rissa tridactyla (Staszewski et al. 2007). In the North Pacific, the presence of Borrelia in ticks has been reported (Olsen et al. 1995, Comstedt et al. 2009, Gómez-Díaz et al., 2011), but little is known about variability in Bbsl exposure within and among seabird communities. North Pacific seabird communities are composed of a rich array of colonial species, and share with the North Atlantic communities both the tick vector I. uriae and some seabird host species (black-legged kittiwake, common murre Uria aalge, and thick-billed murre Uria lomvia). Among the diversity of seabirds that make up these communities, there are several species of particular interest in terms of tick and pathogen exposure; two sister species pairs of seabirds, namely, red-legged Rissa brevirostris and black-legged kittiwakes, and common and thick-billed murres, that breed in similar habitats and may share local tick populations and have similar exposure levels. Likewise, there are also a series of Aethia auklet species, some of which have been suggested to use an odorant as a defence against ticks (Douglas et al. 2004), but whose infestation levels are largely unknown.

In the present work, we estimated the prevalence of antiBorrelia antibodies using a sample of 805 individuals belonging to nine seabird species breeding on six islands of the North Pacific. This large-scale sampling survey in the North Pacific was conducted to (1) investigate interspecific patterns of exposure to $\mathrm{Bbsl}$ in the North Pacific and compare these patterns with those found in the North Atlantic, (2) determine whether there is significant heterogeneity in the distribution of seropositive individuals among colonies within species, and (3) identify those seabird species or groups of species which may be important for the global circulation of Bbsl.

\section{Materials and Methods}

\section{Detection of anti-Borrelia antibodies in seabirds}

Blood samples were collected from 805 breeding adults belonging to nine seabird species: the crested auklet Aethia cristatella, the parakeet auklet Aethia psittacula, the least auklet Aethia pusilla, the common murre, the thick-billed murre, the tufted puffin Lunda cirrhata, the horned puffin Fratercula corniculata, the red-legged kittiwake, and the black-legged kittiwake. Sampling took place on six North Pacific islands (Fig. 1). In 2003 and 2004, samples were collected from Buldir $\left(52^{\circ} 21^{\prime} \mathrm{N} 176^{\circ} 56^{\prime} \mathrm{E}\right)$, St. Paul $\left(57^{\circ} 11^{\prime} \mathrm{N} 170^{\circ} 15^{\prime} \mathrm{W}\right)$, and St. George $\left(56^{\circ} 35^{\prime} \mathrm{N} 169^{\circ} 37^{\prime} \mathrm{W}\right)$. In 2008 , the west Pacific was sampled: Starichkov $\left(52^{\circ} 46.919^{\prime} \mathrm{N}, 158^{\circ} 36.617^{\prime} \mathrm{E}\right)$, Ptichie (Ptichie $1\left[50^{\circ} 30.495^{\prime} \mathrm{N}, 156^{\circ} 17.358^{\prime} \mathrm{E}\right]$ and Ptichie $2\left[50^{\circ} 30.570^{\prime} \mathrm{N}\right.$, $\left.156^{\circ} 16.762^{\prime} \mathrm{E}\right]$ ), and the Commander Islands (Toporkov $\left[55^{\circ} 12.414^{\prime} \mathrm{N}, 165^{\circ} 56.174^{\prime} \mathrm{E}\right]$ and Ary Kamen [55 ${ }^{\circ} 12.842^{\prime} \mathrm{N}$, $\left.\left.165^{\circ} 47.452^{\prime} \mathrm{E}\right]\right)$. Not all nine seabird species could be sampled on each island, notably because not all species are present at these locations (Hunt et al. 1986, Kondratyev et al. 2000, Byrd et al. 2005). We therefore aimed to sample the main species present on each island, so as to obtain representative samples of the local community. Sample sizes for each species and location are specified in Table 1 . As sample sizes were small for the two locations of Ptichie and for the Commander Islands, we pooled the samples within each location. Blood samples

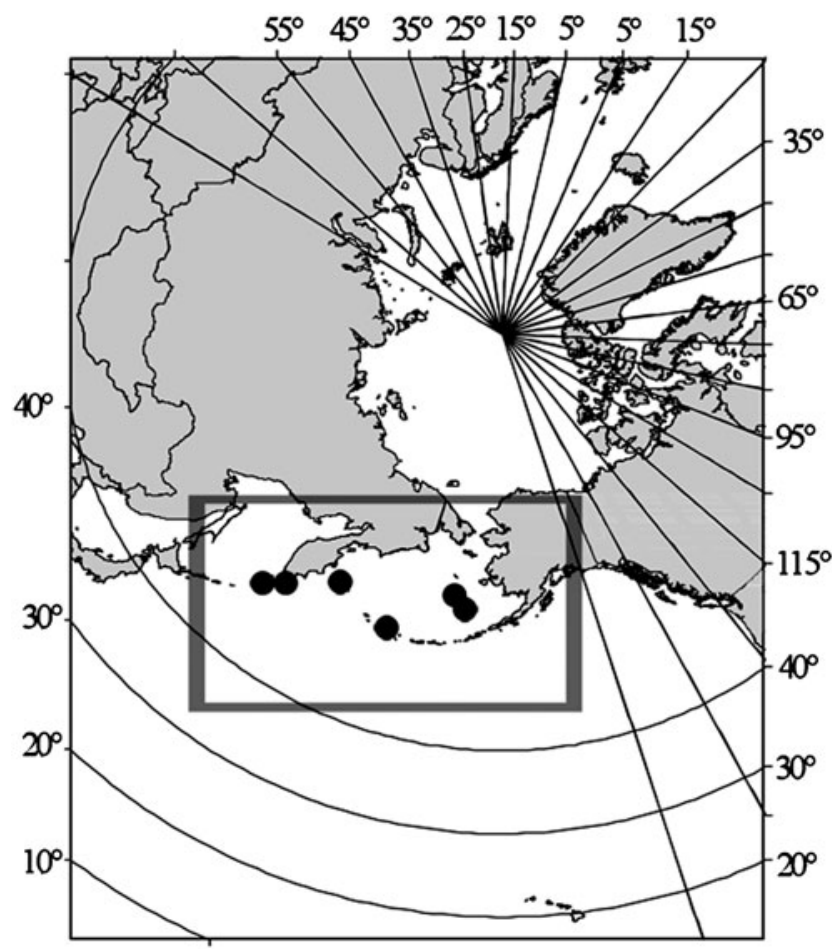

FIG. 1. Geographic location of islands sampled in the North Pacific.

from breeding adult birds were obtained from the left ulnar vein with a sterile syringe (Staszewski et al. 2008). After centrifugation, the plasma was separated from the blood cells and stored at $-20^{\circ} \mathrm{C}$ until immunological analyses.

Anti-Borrelia Ab levels in the plasma were analyzed using a sandwich enzyme-linked immunosorbent assay (ELISA, Enzygnost Lyme VlsE/IgG, Dade Behring). Because this kit was manufactured for human use and was designed to recognize mammalian $\mathrm{Ab}$, we replaced the anti-IgG $\mathrm{Ab}$ of the kit by an anti-chicken IgY (Sigma A-9171) conjugated with phosphatase. We diluted the samples in the buffer provided by the kit (dilution 1/50) and transferred 50 microliters to the ELISA plate wells. The plates were incubated $3 \mathrm{~h}$ at room temperature and then washed 3 times with phosphate-buffered saline (PBS)-Tween. Subsequently, we added $50 \mu \mathrm{L}$ of anti-chicken $\mathrm{Ab}$ conjugated with phosphatase (dilution 1/2000) to the wells and incubated the plates overnight at $4^{\circ} \mathrm{C}$. Plates were washed three times (PBS-Tween) and $100 \mu \mathrm{L}$ of the phosphatase substrate p-nitrophenylphosphate-diethanolamine $(1 \mathrm{mg} / \mathrm{mL})$ was added to the wells. We measured the optical density at $405 \mathrm{~nm}$ at several points over time (every $2.5 \mathrm{~min}$ ) to capture the dynamics of color development and saturation after the addition of the substrate chromogen. The optical density (OD) of the colorimetric reaction after $7.5 \mathrm{~min}$ was used for estimating the Ab levels in the samples as it gave us the best correlation between control samples run in two independent ELISA plates. A group of 8 samples representing a range of optical densities was run on each ELISA plate. A correction equation was then calculated between the OD of these samples on a given plate and that of a chosen reference plate; this equation (corrected $\mathrm{OD}=a \times($ original OD) $+b$ ) was then used to correct the OD of samples on a given plate (all regressions, $r>0.96)$. Most samples were run once in a single 
Table 1. Prevalence of Anti-Borrelia Antibodies in the Plasma of North Pacific Seabirds

\begin{tabular}{|c|c|c|c|c|c|c|c|c|c|}
\hline & $\begin{array}{c}\text { Thick-billed murre } \\
0.18[0.38] \\
(14 / 77)\end{array}$ & $\begin{array}{c}\text { Common murre } \\
0.18[0.38] \\
(28 / 155)\end{array}$ & $\begin{array}{c}\text { Black-legged } \\
\text { kittiwake } \\
0.02[0.16] \\
(4 / 158)\end{array}$ & $\begin{array}{l}\text { Red-legged } \\
\text { kittiwake } \\
0(0 / 101)\end{array}$ & $\begin{array}{c}\text { Tufted puffin } \\
0.13[0.34] \\
(10 / 75)\end{array}$ & $\begin{array}{l}\text { Horned } \\
\text { puffin } \\
0(0 / 27)\end{array}$ & $\begin{array}{c}\text { Least auklet } \\
0(0 / 96)\end{array}$ & $\begin{array}{l}\text { Parakeet } \\
\text { auklet } \\
0(0 / 75)\end{array}$ & $\begin{array}{c}\text { Crested } \\
\text { auklet } \\
0(0 / 41)\end{array}$ \\
\hline $\begin{array}{l}\text { Buldir } \\
0.05[0.21] \\
(8 / 173)\end{array}$ & $\begin{array}{c}0.31[0.46] \\
(8 / 26)\end{array}$ & & $\begin{array}{c}0 \\
(0 / 26)\end{array}$ & $\begin{array}{c}0 \\
(0 / 20)\end{array}$ & $\begin{array}{c}0 \\
(0 / 4)\end{array}$ & $\begin{array}{c}0 \\
(0 / 27)\end{array}$ & $\begin{array}{c}0 \\
(0 / 26)\end{array}$ & $\begin{array}{c}0 \\
(0 / 25)\end{array}$ & $\begin{array}{c}0 \\
(0 / 19)\end{array}$ \\
\hline $\begin{array}{l}\text { St. Paul } \\
0.04[0.19] \\
(7 / 194)\end{array}$ & $\begin{array}{c}0.16[0.37] \\
(3 / 19)\end{array}$ & $\begin{array}{c}0.08[0.28] \\
(3 / 36)\end{array}$ & $\begin{array}{c}0.05[0.21] \\
(1 / 21)\end{array}$ & $\begin{array}{c}0 \\
(0 / 27)\end{array}$ & & & $\begin{array}{c}0 \\
(0 / 42)\end{array}$ & $\begin{array}{c}0 \\
(0 / 27)\end{array}$ & $\begin{array}{c}0 \\
(0 / 22)\end{array}$ \\
\hline $\begin{array}{l}\text { St. George } \\
0.05[0.21] \\
(7 / 154)\end{array}$ & $\begin{array}{c}0.08 \text { [0.27] } \\
(2 / 25)\end{array}$ & $\begin{array}{c}0.06[0.24] \\
(2 / 33)\end{array}$ & $\begin{array}{c}0.17 \text { [0.37] } \\
(3 / 18)\end{array}$ & $\begin{array}{c}0 \\
(0 / 27)\end{array}$ & & & $\begin{array}{c}0 \\
(0 / 28)\end{array}$ & $\begin{array}{c}0 \\
(0 / 23)\end{array}$ & \\
\hline $\begin{array}{l}\text { Starichkov } \\
0.08[0.26] \\
(3 / 40)\end{array}$ & & $\begin{array}{c}0.11[0.31] \\
(3 / 27)\end{array}$ & $\begin{array}{c}0 \\
(0 / 13)\end{array}$ & & & & & & \\
\hline $\begin{array}{l}\text { Commander } \\
0.17[0.38] \\
(26 / 151)\end{array}$ & $\begin{array}{c}0.14 \text { [0.35] } \\
\quad(1 / 7)\end{array}$ & $\begin{array}{c}0.59[0.49] \\
(17 / 29)\end{array}$ & $\begin{array}{c}0 \\
(0 / 39)\end{array}$ & $\begin{array}{c}0 \\
(0 / 27)\end{array}$ & $\begin{array}{c}0.16 \text { [0.37] } \\
(8 / 49)\end{array}$ & & & & \\
\hline $\begin{array}{l}\text { Ptichie } \\
0.05[0.22] \\
(5 / 93)\end{array}$ & & $\begin{array}{c}0.10[0.3] \\
(3 / 30)\end{array}$ & $\begin{array}{c}0 \\
(0 / 41)\end{array}$ & & $\begin{array}{c}0.09[0.29] \\
(2 / 22)\end{array}$ & & & & \\
\hline
\end{tabular}

Antibody prevalence is expressed as the number of positive individuals divided by the total number of individuals analyzed. Numbers in square brackets express the standard deviation of prevalence calculated as sqrt $\left(p^{*}(1-p)\right)$. Fractions in brackets indicate the number of positive individuals with respect to the total number of individuals analyzed. Gray shading highlights the most abundant species in each large colony.

ELISA well. However, intraplate coefficients of variation were calculated by running two to five samples more than once on each plate. Interplate coefficients of variation were calculated using the corrected OD of samples run on different plates.

To verify that immunoglobulins from the seabird species considered here were recognized by anti-chicken antibodies (Martinez et al. 2003), we carried out western blots. For this, plasma samples of the 9 seabird species were diluted $1 / 10$ in SDS-reducing buffer (Laemmli sample buffer containing $0.5 \%$ mercaptoethanol). Plasma proteins ( $3 \mu \mathrm{L}$ diluted $1 / 10$ ) were separated on polyacrylamide gels containing a stacking gel of $4 \%$ and a running gel of $10 \%$. Prestained markers of molecular weight (Spectra Multicolor Broad Range Protein Ladder; Fermentas Life Sciences) were included in all gels. Proteins were transferred to nitrocellulose membranes (Bio-Rad). Blots were then washed with PBS-Tween $0.05 \%$ and incubated overnight at $4^{\circ} \mathrm{C}$ with $5 \%$ nonfat dry milk (Regilait) in PBS-Tween. Membranes were then incubated for $2 \mathrm{~h}$ with an anti-chicken anti-IgY conjugated with peroxidase (Sigma, A-9046) diluted to 1/5000 in 3\% nonfat dry milk in PBS-Tween. After 3 washes with PBSTween, antigen-Ab complexes were observed by chemoluminiscence using the SuperSignal West Pico reagent (Fisher). The anti-chicken $\mathrm{Ab}$ proteins detected corresponded to the apparent molecular weights of heavy and light immunoglobulin chains for all nine seabird species considered in this study (Fig. 2a).

While the ELISA gave us a relative estimate of Ab levels, it was necessary to define specific positivity thresholds as the affinity of anti-chicken antibodies for IgY can vary among the species considered (Staszewski et al. 2008). We did this by performing western blots for the detection of antibodies against Bbsl (EcoBlot Borrelia afzelii+ VlsE; Meridian Bioscience) using a range of plasma samples covering the spectrum of optical densities for each species. Due to sample availability and to optimize costs, the number of samples tested in western blots analyses was 13 for crested auklets, 16 for parakeet auklets, 15 for least auklets, 12 for horned puffins, 27 for tufted puffins, 20 for red-legged kittiwakes, 24 for black-legged kittiwakes, 31 for common murres, and 23 for thick-billed murres. The antigens used in the kit come from the strain of Borrelia afzelii PKo and recombinant VlsE. The antigens relevant for diagnosis used by the kit are VlsE, p83/ 100, p58, p43, BmpA (p39), OspA (p31), p30, OspC (p23), p21, and Osp17; the presence of specific antibodies against each antigen is revealed by the presence of color bands at specific positions. The birds of our study were most likely exposed to Borrelia garinii, as suggested by the genetic studies of Borrelia genospecies isolated from ticks collected from some of these hosts and locations (Gómez-Díaz et al. 2011), although B. burgdorferi sensu stricto and B. afzelii have also been recorded in the marine system (Dietrich et al. 2008, Duneau et al. 2008). The proteins used in serodiagnosis are largely shared by the different species of the Bbsl complex, which should enable the detection of antibodies against these proteins from the different Bbsl species/strains. Moreover, the kit contains a recombinant VlsE, recommended to improve sensitivity to the presence of a variety of Borrelia strains (Wilske et al. 2007). We used the protocol suggested by the kit manufacturer, but substituted the anti-human IgG provided by the kit with antichicken IgY (Sigma A-9171) (Staszewski et al. 2008). Samples were diluted $1 / 100$ and the anti-IgY was used at dilution $1 / 200$. We measured the intensity of the bands using the program ImageJ and declared a band positive if its intensity was higher than the VlsE band of the positive control provided by the kit. A sample was declared positive if at least 2 positive bands were found (see Fig. $2 \mathrm{~b}$ for examples of positive and negative immunoblots). This criterion probably gave 

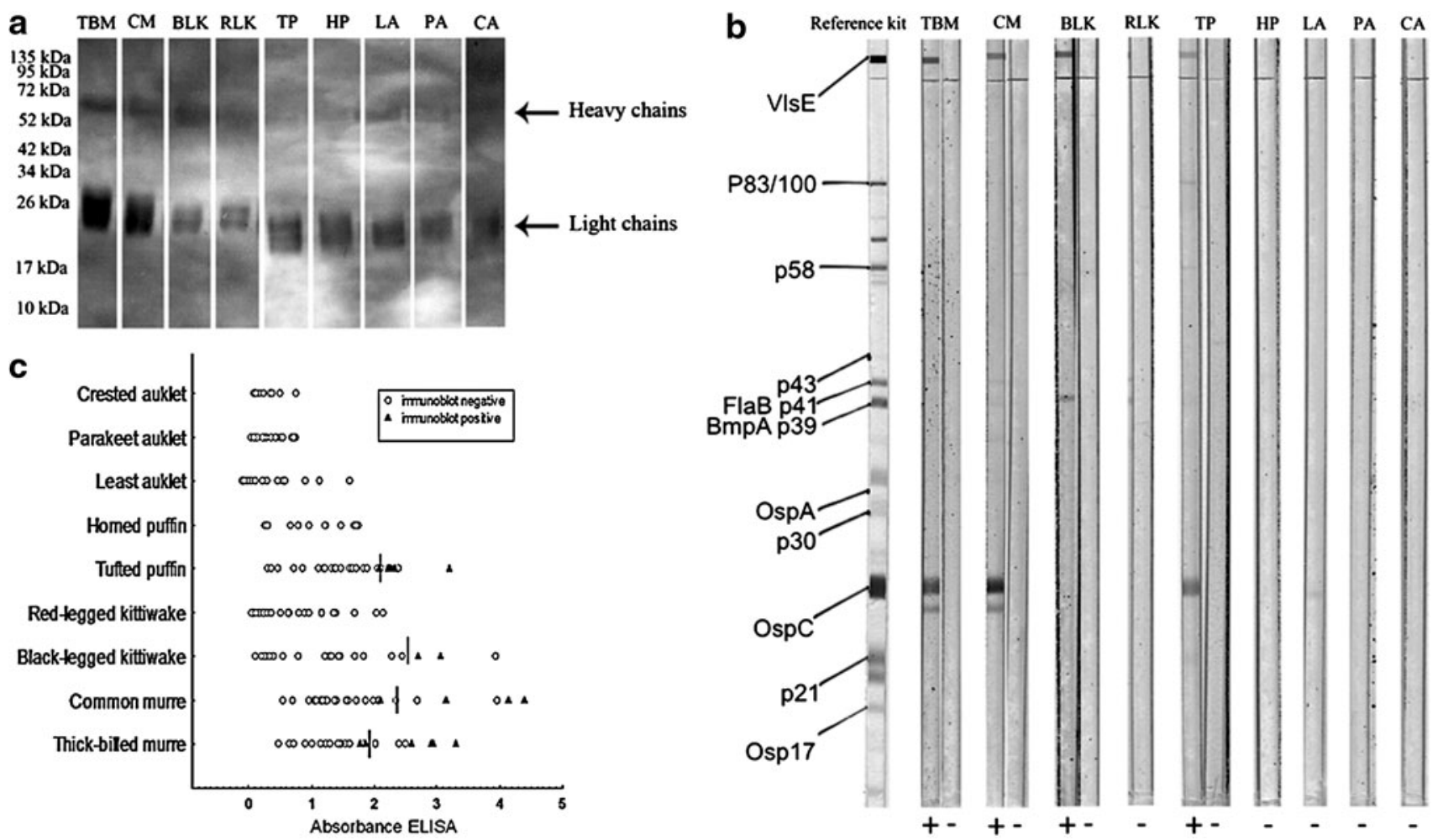

FIG. 2. (a) Recognition of IgY of each species by anti-chicken antibodies by means of western blot. (b) Positive and negative Borrelia immunoblots for each seabird species. We only show negative immunoblots for RLK, HP, LA, PA, and CA, as these species did not show positive immunoblots. The band locations of specific antigens were determined using the reference map provided with the kit. (c) Absorbances obtained in enzyme-linked immunosorbent assay (ELISA) tests of all samples run in immunoblots. The positive ELISA threshold of each seabird species is shown by a vertical line (calculated as the mean optical density minus one standard deviation of all individuals found positive by the western blot). TBM, thick-billed murre; CM, common murre; BLK, Black-legged kittiwake; RLK, red-legged kittiwake; TP, tufted puffin; HP, horned puffin; LA, least auklet; PA, parakeet auklet; CA, crested auklet.

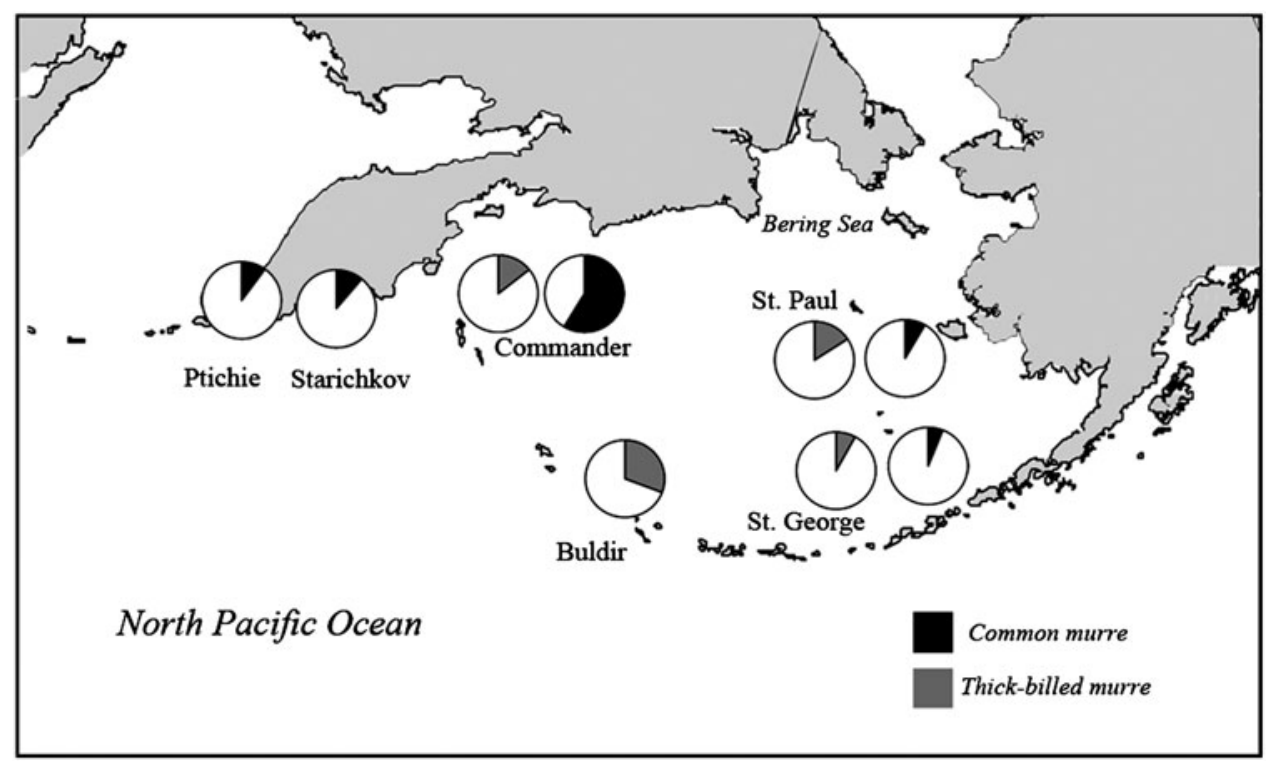

FIG. 3. Prevalence of antibodies against Borrelia burgdorferi sensu lato in common and thick-billed murres. The painted area on each pie chart refers to seropositive individuals, and the white area refers to seronegative individuals for each species and location. Sample sizes are specified on Table 1. St. Paul, St. George, and Commander Islands show two graphs; one for each murre species. 
us a conservative estimate of seropositivity. We ran 10 samples in 2 different immunoblots to calculate a Spearman correlation of band intensities of the different antigens (antigens positive in at least 3 samples: (BmpA (p39), OspA, OspC, p58, and VlsE) and summarized the results by calculating the average of the correlations.

The positive ELISA threshold of each species was calculated as the mean optical density minus one standard deviation of all individuals found positive by the western blot (Fig. 2c). An individual was declared positive for the ELISA if its optical density was above this threshold. This method has been used in previous studies on Borrelia seroprevalence in seabirds and with this calibration, ELISA results can be directly compared among individuals and species (Staszewski et al. 2008).

Differences in prevalence (percentage of seropositive individuals) among species and locations were analyzed using Fisher exact tests, testing each explanatory factor separately. To analyze the effect of species and locations simultaneously, we used only those locations where at least three seabird species were sampled and performed a logistic regression to evaluate the effect of the two explanatory variables on seroprevalence.

\section{Results}

For the ELISA tests, the average intraplate coefficient of variation was $6.85 \%$ (95\% confidence interval [CI] 4.83-8.87, N coefficients of variation $=39$ ). The average interplate coefficients of variation was 30.04\% (95\% CI 27.01-33.07) for uncorrected values and $11.25 \%$ (95\% CI 5.74-16.76, N coefficients of variation $=24$ ) after correction. For the western blot analyses, band intensities were highly correlated between replicate immunoblots (average Spearman $r=0.86 \pm 0.17, N=5$ antigens; BmpA (p39), OspA, OspC, p58, and VlsE).

The global prevalence of anti-Borrelia antibodies in adult seabirds was $7.0 \%$ (positives $=56, N=805$ ). No anti-Borrelia $\mathrm{Ab}$ was detected in five seabird species: the crested auklet $(N=41)$, the parakeet auklet $(N=75)$, the least auklet $(N=96)$, the horned puffin $(N=27)$, and the red-legged kittiwake $(N=101)$. In the four other species in which anti-Borrelia antibodies were detected, prevalence differed among species (Fisher exact test $p<0.001, N=465)$ : common murre $18.1 \%$, thick-billed murre $18.2 \%$, tufted puffin $13.3 \%$, black-legged kittiwake $2.5 \%$ (see Table 1 for details). There was a significant difference in the overall prevalence of Borrelia among islands (Fisher exact test $p<0.001, N=805$ ): Buldir 4.6\%, St. Paul 3.6\%, St. George 4.5\%, Starichkov 7.5\%, Ptichie 5.4\%, and Commander 17.2\%. When considering within species geographic variation in seroprevalence for those species with nonzero prevalence, significant differences in prevalence were observed among islands for common murres and black-legged kittiwakes (Fisher exact test $p<0.05$, Fig. 3): common murres showed the highest prevalence in Commander islands (58.6\%) and blacklegged kittiwakes showed the highest prevalence on St. George $(16.7 \%)$. No significant island effect was observed for thickbilled murres and tufted puffins (Fisher exact test $p>0.05$; Table 1, Fig. 3). When considering only those locations where at least three species were sampled together (St. Paul, St. George, and the Commander Islands for common murres, thick-billed murres, and black-legged kittiwakes), both species and island effects were significantly associated with $\mathrm{Ab}$ prevalence (logistic regression, island effect: Wald $=13.35$, $p=0.0013$, species effect: Wald $=12.74, p=0.0017, n=227$ ).

\section{Discussion}

We demonstrate significant variability in Borrelia seroprevalence among seabird species in the North Pacific. Specific anti-Bbsl antibodies were measured by a quantitative ELISA technique using commercially available secondary anti-chicken antibodies. We defined a positive ELISA threshold for each seabird species using a qualitative western blot technique and verified that immunoglobulins of the studied seabird species were recognized by anti-chicken antibodies. These steps allowed us to determine Bbsl exposure in the nine focal seabird species. Only four of these nine species showed evidence of an immune response to Bbsl, suggesting that some species are unlikely to contribute to Borrelia circulation. Likewise, seropositive species differed in their relative prevalence; the highest seroprevalence was found for the two murre species, a result consistent with observations in the North Atlantic (Staszewski et al. 2008). Consequently, among the seabird species sampled, murres may be the main species implicated in the global circulation of Borrelia spirochetes and should be targeted for further study, especially with respect to the duration of infection, reservoir competence and dispersal.

Interspecific differences in $\mathrm{Ab}$ prevalence may be due to several alternative factors. First, there may be strong interhost variability in exposure to tick vectors. For instance, high breeding densities in surface-nesting murres may increase their exposure to ticks compared with auklets, kittiwakes, and puffins, which usually breed at lower densities in individual burrows, nests or crevices (Cramp and Simmons 1983, Gaston and Jones, 1998). It is also possible that some species repel ectoparasites such as ticks by producing volatile odorants, as is the case in crested auklets (Douglas et al. 2004). However, differences in anti-Borrelia $\mathrm{Ab}$ prevalence cannot be explained purely by differences in vector presence. Some seabirds, such as red-legged kittiwakes and parakeet auklets, showed $0 \%$ prevalence of $\mathrm{Bbsl}$ antibodies, but are known to host I. uriae and to be present in the same colonies as seropositive birds (see Table 1). Alternatively, differences in seroprevalence may be due to host specialisation in tick vector. In the North Atlantic and sub-Antarctic, evidence of host-associated genetic structure has been found for I. uriae (McCoy et al. 2001, 2005b, Kempf et al. 2009), along with differences in Borrelia prevalence and intensity among sympatrically occurring tick races (Duneau et al. 2008, Gómez-Diaz et al. 2010). Information on the population genetic structure of I. uriae within North Pacific colonies will be now required to test the potential role of vector specialisation in determining patterns of Bbsl exposure. Finally, the different seabird species considered here may represent different environments for microparasites in terms of the resistance conferred by their immune system. Indeed, acquired resistance has been suggested to explain differential detection of Great Island virus in ticks feeding on juvenile and adult common murres (Nunn et al. 2006a, 2006b). The immune response has also been associated with observations of interspecific differences in reservoir competence of different host species of LB spirochetes in terrestrial systems (Kurtenbach et al. 2006).

Our results also indicated significant spatial variability in anti-Borrelia seroprevalence among locations. Anti-Borrelia Ab prevalence in birds was highest in the Commander Islands; this is consistent with a high spirochete prevalence reported in I. uriae ticks collected from the vegetation on these islands 
(Comstedt et al. 2009). The global and local prevalence of anti-Borrelia antibodies we observed in the North Pacific is, nevertheless, much lower than that observed in the North Atlantic for black-legged kittiwakes (global prevalence of $18.6 \%$ ) and common murres (global prevalence of $77.1 \%$ ) (Staszewski et al. 2008). The extent to which community composition explains differences in seroprevalence among Atlantic and Pacific colonies may strongly depend on within host species spatial variability in tick exposure (Gasparini et al. 2001, Staszewski et al. 2007) and the potential transmission constraints imposed by host specialisation in the tick vector (Duneau et al. 2008). Other environmental factors that differ between regions and affect food availability, host physiological states, and inter-colony movement patterns could also affect host infection status and pathogen prevalence (Gylfe et al. 2000, Kitaysky et al. 2001). To better understand the implications of interspecific and inter-locality differences in host prevalence in relation to parasite transmission, future studies will need to examine the relative contribution of host ecology, vector ecology, and immunology to the patterns observed here. A better identification of the links that exist between the marine and terrestrial cycles of $B b s l$ is also needed to understand large-scale eco-epidemiological patterns of human Lyme disease.

\section{Acknowledgments}

We thank John Citta, Chris Barger, Morgan BenowitzFredericks, Tom Dempsey, Ine Dorresteijn, Hector Douglas, Ann Harding, Anne Ploshnitsa, Mike Shultz, Rebecca Young, and Sarah Youngren, for their help during collection of samples in the field. Permissions to work in the study areas were obtained from local authorities. Sampling of birds in the eastern North Pacific was authorized by the Institutional Animal Care and Use, University of Alaska Fairbanks, and under all required federal and state permits. Dr. Nikolay N. Pavlov, Director, Komandorskiy State Nature Biosphere Reserve, Dr. Yuri Artukhin and Dr. Sergey V. Zagrebelny are commended for their professional guiding and logistic support. We thank Bruno Buatois (Plate-forme d'Analyse Chimique, CEFE) and Rudolphe Hamel and Dorothée Misse (MIVEGEC) for technical support. Thanks to Doris Gómez and Julien Vézilier for their help with figures. We thank two anonymous reviewers for their constructive comments. E. L. was supported by the program "Contratos para Investigación Posdoctorales, incluidas las ayudas para Becas Mec/Fullbright y Cátedras Príncipe de Asturias" from "Ministerio de Ciencia e Innovacion" of Spain. J. P.-D. was supported by a Chateaubriand postdoctoral fellowship from the French government. E. G.-D. was supported by a Marie Curie fellowship no. PIEF-GA-2008-221243. Field work and analyses were funded by grants from North Pacific Research Board, projects 320, B67, B77 to ASK and EPSCoR University of Alaska Fairbanks, CNRS Interdisciplinary Emerging Infectious Disease program, the French Polar Institute (Institut Polaire Français Paul Emile Victor program 333 on the ecology of dispersal of seabirds and ticks), and the Agence National de la Recherche (ANR-06-JCJC-0095-01)).

\section{Disclosure Statement}

No competing financial interests exist.

\section{References}

Brinkerhoff, RJ, Folsom-O'Keefe, CM, Tsao, K, Diuk-Wasser, MA. Do birds affect Lyme disease risk? Range expansion of the vector-borne pathogen, Borrelia burgdorferi. Front Ecol Environ 2009; 9:103-110.

Byrd, VG, Renner, HM, Renner, M. Distribution patterns and population trends of breeding seabirds in the Aleutian Islands. Fish Oceanogr 2005; 14:139-159.

Choe, JC, Kim, KC. Community structure of arthropod ectoparasites on Alaskan seabirds. Can J Zool 1987; 65:2998-3005.

Comstedt, P, Asokliene, L, Eliasson, I, Olsen, B, et al. Complex population structure of Lyme borreliosis group spirochete Borrelia garinii in Subartic Eurasia. PLoS ONE 2009; 4:1-9.

Comstedt, P, Bergström, S, Olsen, B, Garpmo, U, et al. Migratory passerine birds as reservoirs of Lyme Borreliosis in Europe. Emerging Infect Dis. 2006; 12:1087-1095.

Cramp, S, Simmons, KEL. Handbook of the Birds of Europe, the Middle East and North Africa, Vol. 3. Oxford UK; Oxford University Press, 1983.

Dietrich, M, Gómez-Díaz, E, Boulinier, T, McCoy, KD. Local distribution and genetic structure of tick-borne pathogens: an example involving the marine cycle of Lyme disease. In: Proceedings of the Vith Congress of the European Association of Acarologists 2008; 33-42.

Dietrich, M, Gómez-Díaz, E, McCoy, KD. Worldwide distribution and diversity of seabird ticks: implications for the ecology and epidemiology of tick-Borne pathogens. Vector Borne Zoonotic Dis 2011; 11:453-470.

Douglas, HD, III, Co, JE, Jones, TH, Conner, WE. Interspecific differences in Aethia spp. Auklet odorants and evidence for chemical defense against ectoparasites. J Chem Ecol 2004; 30:1921-1934.

Dubska, L, Literak, I, Kocianova, E, Taragelova, V, et al. Differential role of passerine birds in distribution of Borrelia spirochetes, based on data from ticks collected from birds during the postbreeding migration period in Central Europe. Appl Environ Microbiol 2009; 75:596-602.

Duneau, D, Boulinier, T, Petersen, A, Tveraa, T, et al. Prevalence and diversity of Lyme borreliosis bacteria in marine birds. Infect Genet Evol 2008; 8:352-359.

Gasparini, J, McCoy, KD, Haussy, C, Tveraa, T, et al. Induced maternal response to the Lyme disease spirochaete Borrelia burgdorferi sensu lato in a colonial seabird, the kittiwake Rissa trydactyla. Proc R Soc B 2001; 268:647-650.

Gaston, AJ, Jones, IL. The Auks. Oxford UK; Oxford University Press, 1998.

Gauthier-Clerc, M, Jaulhac, B, Frenot, Y, Bachelard, C, et al. Prevalence of Borrelia burgdorferi (the Lyme disease agent) antibodies in king penguin Aptenodytes patagonicus in Crozet Archipielago. Polar Biol 1999; 22:141-143.

Gómez-Díaz, E, Boulinier, T, Sertour, N, Cornet, M, et al. Genetic structure of marine Borrelia garinii and population admixture with the terrestrial cycle of Lyme borreliosis. Environ Microbiol 2011 [Epub ahead of print]; DOI: 10.1111/j.14622920.2011.02515.x.

Gómez-Díaz, E, Doherty, PF, Duneau, D, McCoy, KD. Cryptic vector divergence masks vector-specific patterns of infection: an example from the marine cycle of Lyme borreliosis. Evol Appl 2010; 3:391-401.

Gylfe, A, Bergström, S, Lundstrom, J, Olsen, B. Epidemiology: reactivation of Borrelia infection in birds. Nature 2000; 403:724-725.

Gylfe, A, Olsen, B, Strasevicius, D, Ras, NM, et al. Isolation of Lyme disease Borrelia from puffins (Fratercula artica) and 
seabird ticks (Ixodes uriae) on the Faeroe Islands. J Clin Microbiol 1999; 37:890-896.

Hunt, GL, Eppley, ZE, Schneider, DC. Reproductive performance of seabirds: the importance of population and colony size. Auk 1986; 103:306-317.

Kempf, F, Boulinier, T, De Meeûs, T, Arnathau, C, et al. Recent evolution of host-associated divergence in the seabird tick Ixodes uriae. Mol Ecol 2009; 18:4450-4462.

Kitaysky, AS, Kitaiskaia, EV, Wingfield, JC, Piatt, JF. Dietary restriction causes chronic elevation of corticosterone and enhances stress response in red-legged kittiwake chicks. J Comp Physiol B 2001; 171:701-709.

Kondratyev, AY, Litvinenko, NM, Kaiser, GW. Seabirds of the Russian Far East. Ottawa: Canadian Wildlife Service, 2000.

Kurtenbach, K, Hanincová, K, Tsao, JI, Margos, G, et al. Fundamental processes in the evolutionary ecology of Lyme borreliosis. Nature Rev Microbiol 2006; 4:660-669.

Kurtenbach, K, Peacey, M, Rijpkema, SG, Hoodless, AN, et al. Differential transmission of the genospecies of Borrelia burgdorferi sensu lato by game birds and small rodents in England. Appl Environ Microbiol 1998; 64:1169-1174.

Martinez, J, Tomas, G, Merino, S, Arriero, E, et al. Detection of serum immunoglobulins in wild birds by direct ELISA: a methodological study to validate the technique in different species using antichicken antibodies. Funct Ecol 2003; 17:700706.

McCoy, KD. The population genetic structure of vectors and our understanding of disease epidemiology. Parasite 2008; 15:444448.

McCoy, KD, Boulinier, T, Tirard, C. Comparative host-parasite population structures: disentangling prospecting and dispersal in the Black-legged kittiwake Rissa tridactyla. Mol Ecol 2005a; 14:2825-2838.

McCoy, KD, Boulinier, T, Tirard, C, Michalakis, Y. Host specificity of a generalist parasite: genetic evidence of sympatric host races in the seabird tick Ixodes uriae. J Evol Biol 2001; 14:395-405.

McCoy, KD, Chapuis, E, Tirard, C, Boulinier, T, et al. Recurrent evolution of host-specialized races in a globally distributed parasite. Proc R Soc B 2005b; 272:2389-2395.
Nunn, MA, Barton, TR, Wanless, S, Hails, RS, et al. Tick-borne Great Island virus: (I) identification of seabird host and evidence for co-feeding and viraemic transmission. Parasitology 2006a; 132:233-240.

Nunn, MA, Barton, TR, Wanless, S, Hails, RS, et al. Tick-borne Great Island virus: (II) impact of age-related acquired immunity on transmission in a natural seabird host. Parasitology 2006b; 132:241-253.

Olsen, B, Duffy, DC, Jaenson, TGT, Gylfe, A, et al. Transhemispheric exchange of Lyme disease spirochetes by seabirds. J Clin Microbiol 1995; 33:3270-3274.

Olsen, B, Jaenson, TGT, Noppa, L, Bunikis, J, Bergstöm, S. A Lyme borreliosis cycle in seabirds and Ixodes uriae ticks. Nature 1993; 362:340-342.

Schreiber, EA, Burger, J. Biology of Marine Birds. Boca Raton, FL: CRC Press, 2001.

Smith, RP, Bin Muzaffar, S, Lavers, J, Lacombe, EH, et al. Borrelia garinii in seabird ticks (Ixodes uriae), Atlantic coast, North America. Emerg Infect Dis 2006; 12:1909-1912.

Staszewski, V, McCoy, KD, Boulinier, T. Variable exposure and immunological response to Lyme disease Borrelia among North Atlantic seabird species. Proc R Soc B 2008; 275:21012109.

Staszewski, V, McCoy, KD, Tveera, T, Boulinier, T. Interannual dynamics of antibody levels in naturally infected long-lived colonial birds. Ecology 2007; 88:3183-3191.

Wilske B, Fingerle V, Schulte-Spechtel, U. Microbiological and serological diagnosis of Lyme borreliosis. FEMS Immunol Med Microbiol 2007; 49:13-21.

Address correspondence to: Elisa Lobato

Centre d'Ecologie Fonctionnelle et Evolutive CNRS UMR 5175

1919 Route de Mende Montpellier F-34293

France

E-mail: elisa.lobato@cefe.cnrs.fr 
